\title{
Teaching NeuroImages: Pathology and thromboembolism of carotid web
}

Yan Ma, MD, Bin Yang, MD, and Liqun Jiao, MD

Neurology ${ }^{\circledR}$ 2020;94:e762-e763. doi:10.1212/WNL.0000000000008965

Figure $1 \mathrm{CT}$ angiography

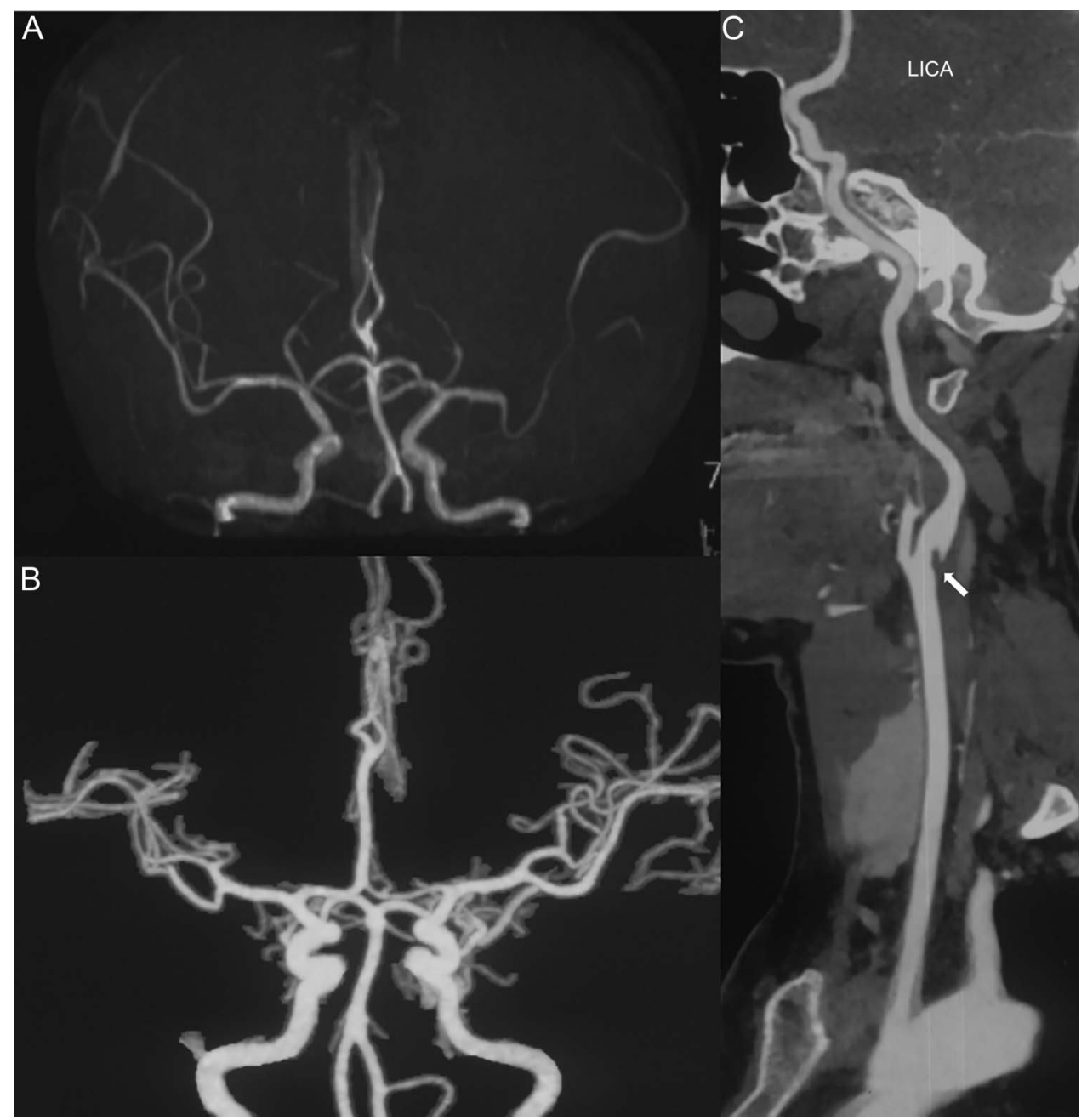

(A, B) Distal M1 segment of the left middle cerebral artery occlusion and complete spontaneous recanalization. (C) Shelf-like protrusion (arrow) arising from the posterior wall of the left carotid bulb.

A 43-year-old woman without relevant medical history presented with acute middle cerebral artery (MCA) occlusion (figure 1A). Thrombophilia and vasculitis were ruled out and echocardiography was normal. Carotid web was considered because a shelf-like protrusion arising from the left carotid bulb (figure 1C) was found, which is suspected as the cause of embolization in MCA. ${ }^{1}$ Carotid endarterectomy was performed. The diaphragm-like structure demonstrated smooth muscle cell-rich intima, increased elastic tissue, and myxoid

\section{Correspondence}

Dr. Jiao

liqunjiao@sina.cn

From the Department of Neurosurgery, Xuanwu Hospital, Capital Medical University, Beijing, China.

Go to Neurology.org/N for full disclosures. Funding information and disclosures deemed relevant by the authors, if any, are provided at the end of the article. 




(A) High-power hematoxylin \& eosin stain shows smooth muscle cell-rich intima with myxoid degeneration. (B) Gross specimen shows smooth contour (arrow) located in the lateralposterior wall of the internal carotid artery and superimposed thrombosis (arrowhead) over the web pocket. (C) Elastic stain image demonstrates hyperplasia of elastic tissue and thrombus (arrow) in web pocket.

degeneration (figure 2, A and B). The superimposed thrombosis was identified in the web pocket (figure 2C). Postoperative CT angiography showed spontaneous recanalization of left MCA (figure 1B).

\section{Author contributions}

Y. Ma: drafting/revising the manuscript, data acquisition, accepts responsibility for conduct of research and final approval, acquisition of data. B. Yang: data acquisition, accepts responsibility for conduct of research and final approval, acquisition of data, study supervision. L. Jiao: drafting/ revising the manuscript, study concept or design, accepts responsibility for conduct of research and final approval, study supervision.

\section{Acknowledgment}

The authors thank the patient and her family for permission to report this case and Dr. Jiang Ying and Zhao Jing for pathologic analysis.

\section{Study funding}

No targeted funding reported.

\section{Disclosure}

The authors report no disclosures relevant to the manuscript. Go to Neurology.org/N for full disclosures.

\section{Reference}

1. Coutinho JM, Derkatch S, Potvin AR, et al. Carotid artery web and ischemic stroke: a case-control study. Neurology 2017;88:65-69. 


\section{Neurology}

\section{Teaching NeuroImages: Pathology and thromboembolism of carotid web Yan Ma, Bin Yang and Liqun Jiao}

Neurology 2020;94;e762-e763 Published Online before print February 3, 2020 DOI 10.1212/WNL.0000000000008965

This information is current as of February 3, 2020

Updated Information \& Services

References

Subspecialty Collections

Permissions \& Licensing

Reprints including high resolution figures, can be found at: http://n.neurology.org/content/94/7/e762.full

This article cites 1 articles, 1 of which you can access for free at: http://n.neurology.org/content/94/7/e762.full\#ref-list-1

This article, along with others on similar topics, appears in the following collection(s):

CT

http://n.neurology.org/cgi/collection/ct

Embolism

http://n.neurology.org/cgi/collection/embolism

Infarction

http://n.neurology.org/cgi/collection/infarction

Stroke in young adults

http://n.neurology.org/cgi/collection/stroke_in_young_adults

Information about reproducing this article in parts (figures,tables) or in its entirety can be found online at:

http://www.neurology.org/about/about_the_journal\#permissions

Information about ordering reprints can be found online:

http://n.neurology.org/subscribers/advertise

Neurology ${ }^{\circledR}$ is the official journal of the American Academy of Neurology. Published continuously since 1951, it is now a weekly with 48 issues per year. Copyright (C 2020 American Academy of Neurology. All rights reserved. Print ISSN: 0028-3878. Online ISSN: 1526-632X.

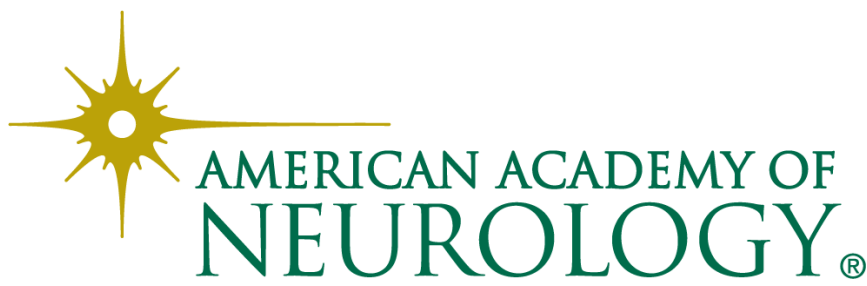

